\title{
A Double Hurdle Estimation of Crop Diversification Decisions by Smallholder wheat Farmers in Sinana District, Bale Zone, Ethiopia
}

Dereje Derso ( $\nabla$ derejso@gmail.com )

MWU: Madda Walabu University

\section{Degefa Tolossa}

Addis Ababa University College of Development Studies

Abrham Seyoum

Addis Ababa University College of Development Studies

\section{Research Article}

Keywords: Crop Diversification, Double hurdle, Determinants, Sinana District, Bale Zone

Posted Date: February 10th, 2022

DOl: https://doi.org/10.21203/rs.3.rs-1256734/v1

License: (c) (i) This work is licensed under a Creative Commons Attribution 4.0 International License. Read Full License 


\section{Abstract}

Background: Ethiopia is heterogeneous in agro-ecological, social, and economic conditions. In such heterogeneous environment, crop production needs to be diversified to meet household consumption and market needs. This study analyzed determinants of crop diversification in wheat dominant producer rural households in Ethiopia's Sinana District of the Oromia Regional State. The study utilized a structured survey of 384 households, and both inferential and descriptive statistics were employed to analyze the data. A Cragg's double hurdle model was applied to identify factors influencing decision and the extent of crop diversification.

Results: We found that decision to crop diversification was positively associated with household size, access to fertile farm plots, and access to extension services and negatively associated with age of household head, and participation in off/non-farm activities. The extent of crop diversification is positively associated with access to extension services, labor availability, membership to farmers cooperatives, and distance to market.

Conclusions: These findings support the need for resources to strengthen available extension packages, support existing farmers' cooperatives, and develop rural infrastructures in order to improve the smallholder farmers' extent of crop diversifications.

\section{Background}

In sub-Saharan Africa, the agricultural sector is key for spurring economic growth, overcoming poverty, and enhancing food security (Michler \& Josephson, 2017). However, in this region, agriculture is often characterized by low productivity (Kassie, Shiferaw, \& Geoffrey, 2011). This is due to several factors, including limited natural resources, socio-economic, technological, and infrastructure problems (FAO et al., 2017).Improving the productivity, profitability and sustainability of smallholder agriculture is the main outcomepoverty in developing countries in general and sub-Saharan Africa in particular (Dillon \& Barret, 2017).

Block and Timmer (1994) and Pellegrini and Tasciotti (2014) noted that crop-diversification increases farm income, creates employment opportunities, reduces poverty, and enhances soil health and water retention. Through crop diversification, farm families can spread production and economic risk over a wider range of crops, thereby reducing financial risks associated with adverse weather conditions or market shocks. Growing diverse products can also help financially by expanding market potential (Truscott et al., 2009). Further, diverse cropping systems generally provide more varied and healthier food for humans and livestock. As noted by FAO (2017) and Acharya et al. (2011) crop diversification is used as one of the fundamental instruments for ensuring food security, poverty reduction, and nutritional adequacy and is a source of overall agricultural development in most developing countries. The inclusion of a variety of crops, in some regions, may lead to development of new agricultural industries, improving the economic potential of a rural community. 
Theoretically, there are two main pathways through which crop diversification affects farm household poverty. (i) it can enhance access to a wide variety of food products necessary for a balanced diet for the households. As diversified production improves dietary diversity, it can enhance the nutritional balance of people's diet and, in doing so, help improve their health and earning capacity, (ii) Farming diversified crops including marketable higher-value crops can lead to increased income for farm families (Mazunda et al., 2018).

The increasing risks of crop failure due to erratic rainfall and crop disease usually force farmers to diversify their portfolio as a hedge against these risks (Asante et al., 2017; Khanal and Mishra, 2017). Concurrently, Winters, Cavatassi, and Lipper (2006) have identified three key factors that derive farmers' 'demand' for crop diversity: managing risk, adapting to heterogeneous agro-ecological production conditions, and meeting market demands and food and nutritional security. Likewise, studies (FAO, 2012; Feliciano, 2019) indicated that crop diversification has beneficial effects for the soil. This is mainly because crop diversification usually associated with reduced weed and insect pressures, reduced need for nitrogen fertilizers (especially if the crop mix include leguminous crops), and reduced erosion (because of cover crops inclusion) (Lin, 2011). It also potentially reduces pests and diseases as well as increases food security by offering farmers access to sufficient, nutritious and diverse foods in areas where markets are not available (Mukherjee, 2015; Van den Broeck, andamp; Maertens, 2016). Furthermore, it has also argued that diversifying by growing more enterprises may lead to farm income stability (Mazunda et al., 2018). Indeed, Habte and Krawinkel (2012) found that pulses are more profitable than most cereals. In addition, the FAO (2016) reported that the economic benefit of faba bean production is 70 percent greater than that of wheat.

In Ethiopia, agriculture continues to be the dominant economic sector in terms of share in the gross domestic product (GDP) (34.9 percent), employment generation (80 percent), and share of export (70 percent), and it provide about 70 Percentage of raw materials for the country industries during the 2015/16 fiscal year (UNDP, 2016). Major Ethiopian policy documents related to economic growth and poverty reduction strategies, place emphasis on the importance of agricultural diversification. Specifically, the Agricultural Development Led Industrialization (ADLI) and the Growth and Transformation Plans (GTPS) I and II embodied all aspects of diversification (Ministry of Finance and Economic Development [MoFED], 2015).

Even though it has been emphasized in public policy, crop diversification in Ethiopia is not well practiced (Mesfin, Fufa \& Haji, 2011; Sibhatu, Krishina \& Qaim, 2015; Mussema et al., 2015; Martin et al., 2016). In the Sinana District, agriculture is traditional, and dominated by monoculture cropping system. Productivity is constrained by several factors such as technology, resources availability, environmental factors, socioeconomic conditions, poor infrastructure, low soil fertility, and crop pests and insects (Bale Zone Finance and Economic Development [BZFED], 2018). Farmers in this monocropping region are therefore vulnerable to marketing risks, income instability, and hunger.

Different studies (including Fetien et al., 2009; Wondimagegn et al., 2011; Degye, Belay, \& Mengistu, 2012; Mandal \& Bezbaruah, 2013; Kanyua et al., 2013; Veljanoska 2014; Ainembabazi \& Mugisha, 2014; Rehima et al., 2013; 2015; Hitayezu, Zegeye \& Ortmann, 2016; Eisenhauer, 2016; World Bank, 2018) have identified that 
crop diversification is shaped by various factors within the farming households. These include available inputs such as labor, farm experience, availability of seed, prices, government policy, land availability, market access, extension service, household characteristics as well as environmental factors such as climatic and soil conditions. However there has been limited research examining determinants of crop diversification at the household level in study area. Therefore, this study was intended to identify and analyze the factors affecting the decision and extent of crop diversification by rural households in the Sinana District for the first time. The findings of this study contribute to the growing body of crop diversification literature. It can also be used as an input to improve production income, food and nutrition security, and poverty reduction for most rural households elsewhere in monocroping areas of Ethiopia.

\section{Theoretical Framework Of The Study}

Agricultural production is subject to complex socioeconomic and environmental constraints. As stated by Singh, Squire, and Strauss, (1986) households' decision is to ensure a balance between production, consumption and labor input. Farmers' production decision objectives go beyond profit maximization, comprising multiple objectives, namely profit, risk and crop complexity (Van Dusen and Taylor, 2005). The objective of smallholder agriculture households is to maximize utility as consumers, unlike the traditional theory of profit maximization (Singh, Squire, \& Strauss, (1986).

The analytical model used for this study was drawn from the theory of the farm household model (De Janvry, Fafchamps, \& Sadoulet, 1991). The household combines farm resources and family labor to maximize utility over consumption goods produced on the farm or purchased on the market. Household decisions are constrained by a production technology, farm physical environment and land area, family labor time allocated to labor and leisure and income constraint.

A farm household's expected utility is dependent on its attitude toward risk. Even in a one-season model, a farm household's utility is subject to uncertainty in, levels of rainfall, output prices, and consumption prices. A farmer's production decisions, including optimal crop allocation, are therefore dependent on that farmer's attitude toward risk (Fafchamps, 1992; Van Dusen and Taylor, 2005) as well as the presence of markets problems (De Janvry, Fafchamps, \& Sadoulet, 1991; Hitayezu Hitayezu et al. (2016). For example, markets for price information or crop insurance would decrease a farmer's perceived level of risk, affecting crop allocation decisions. The literature (Hitayezu et al. 2016) suggests that farmers in developing countries tend to be risk averse and crop diversification may be a strategy to insure against production and price risk.

These conditions pose risks to farm production and make farmers cautious in their farming decisions. Hence, farmers are assumed to use the risk-aversion strategy and maximize utility in their decision-making process. As a mechanism for incorporating risk aversion into a farmer's decision-making process, crop diversification played a vital role (Davis et al., 1987).

The analytical framework used for this study was drawn from both risk-averse and utility-maximizing theories of farm household production behavior. The fundamental assumption is that the farmer's decision on whether to minimize risks (diversify crops) or not is based upon the utility- maximization theory (Ellis, 1993; Rahm \& Huffman, 1984). 
The expression $U\left(C D_{j i} * P_{j i}\right)$ is a non-observable underlying utility function, which ranks the preference of the $i^{\text {th }}$ farmer for the $j^{\text {th }}$ diversification process or status of diversification $(j=0,1$; where $0=$ no diversification and $1=$ diversification). Thus, the utility derived from crop diversification depends on $C D$, which is a vector of demographic, socio-economic, farm specific, marketing and institutional attributes of the diversifier and $P$, which is a vector of the attributes associated with crop diversification. Although the utility function is unobserved, the relation between the utility derivable from the $\mathrm{j}^{\text {th }}$ diversification process is postulated to be a function of the vector of explanatory variables and a disturbance term having a zero mean:

$$
U_{j i}=\alpha_{j} F\left(C D_{i} P_{i}+\epsilon_{j i}\right)
$$

Since the utilities $U_{j i}$ are random, the $i^{\text {th }}$ farmer will select the alternative $j=1$ if $U_{1 i}>U_{0 i}$ or if

\section{the non-observable (latent) random variable $Y^{*}=U_{1 i}-U_{0 i}>0$. The probability that $Y_{i}$ equals one}

\section{(i.e., that the farmer practices crop diversification) is a function of the explanatory variables:}

$P_{i}=\operatorname{Pr}\left(p_{i}=1\right)=\operatorname{Pr}\left(U_{1 i}>U_{0 i}\right)$

$=$

$\operatorname{Pr}\left(\alpha_{1} F_{1}\left(C D_{i}^{*} P_{i}\right)+\epsilon_{1 i}\right)>\operatorname{Pr}\left(\alpha_{0} F_{1}\left(C D_{i}^{*} P_{i}\right)+\epsilon_{0 i}\right)$

$=\operatorname{Pr}\left[\left(\epsilon_{1 i}-\epsilon_{0 i}\right)>F_{i}\left(C D_{i}^{*} P_{i}\right)\left(\alpha_{1}-\alpha_{0}\right)\right]$

$=\operatorname{Pr}\left(v_{i}>-F_{i}\left(C D_{i}^{*} P_{i}\right) \beta\right)$

$=F_{i}\left(X_{i}, \beta\right)(2)$

Where $X$ is the $n \times k$ matrix of the explanatory variables and $\beta$ is a $k \times 1$ vector of parameters to be estimated, $\operatorname{Pr}($.$) is the probability function, v_{i}$ is the random error term, and $\operatorname{Fi}(X i \beta)$ is the cumulative distribution function for $v_{i}$ evaluated at $X_{i} \beta$. The probability that a farmer will diversify in crop production is a function 
of the vector of explanatory variables and of the unknown parameters and error term. Equation 2 cannot be estimated directly without knowing the form of $F$. It is the distribution of $v_{i}$ that determines the distribution of $F$. The functional form of $F$ is specified with double hurdle model. It is used to assess the determinants of crop diversification as well as the factors influencing the extent of crop diversification by rural households.

\section{Material And Methods}

\section{Description of the Study Area}

The study was conducted in Sinana District, Bale Zone, Oromia Regional State of Ethiopia. The District is located in the southwest of Ethiopia and is $412 \mathrm{~km}$ from Addis Ababa, capital city of the country. Robe Town is the major town of the District and of the center of the Zone. In the District, agriculture (crop and livestock production) is dominant livelihood strategies of rural households. Farmers in the District utilize mixed farming system of both crops and livestock. The major crops produced in the District are cereals (wheat, barley, maize, and teff), pulses (bean, field pea), and oil crops (Bale Zone Agriculture Development Organization [BZADO], 2017).

In addition to farming activities, off-farm and non-farm activities were also practiced in small scale. Offfarm activities such as wage employment, participation in crop production on someone else's land for harvest share (especially very small land size holders) were commonly practiced. In the study site, two Kebeles (the lowest administrative unit) out of six were identified as food insecure (BZADO, 2017). In response to this level of food insecurity in the District, the Productive Safety Net Program (a livelihoods supporting scheme) was the major food insecurity intervention (BZADO, 2017).

\section{Data Collection}

A combination of quantitative and qualitative data were collected from primary and secondary sources. Primary data was collected from rural households through structured and semi-structured survey. To complement this primary data, secondary data was collected from records of government officials, published and unpublished reports, journals, books, and websites. The survey interview guide, which consists of structured and semi-structured questions, was prepared in English and translated into the local language (Afan Oromo) to collect information on socio-economic, demographic, and characteristics of households. Furthermore, it was pretested in Kebele, different from sampled Kebeles, and necessary adjustments were made before the actual survey.

\section{Sampling Design}

To select the sampled respondents, a multistage sampling procedure was employed. In the first stage, the Sinana District was purposely selected from ten districts of the Bale Zone due to dominance of wheat production. In the second stage, six kebeles, namely llu-sanbitu, Hamida, Hisu, Salka, Robe-Akababi and Weltei-berisa were selected based on a simple random sampling method. In the third stage, 384 sampled households were selected by using a simple random sampling technique following a scientific sample size determination formula developed by Yamane (1967). 


$$
\mathrm{n}=N /\left(1+N \mathrm{e}^{2}\right) 9768 /\left(1+9768 * 0.05^{2}\right)=384
$$

Where $\mathbf{n}$ is sample size to be included in this study, $\mathbf{N}$ is population size and $\mathbf{e}$ level of precision.

\section{Data Analysis}

In this study STATA software version 14.2 was used to analyze data. The $t$ test was used to assess mean differences between crop diversifier and non-diversifier as well as continuous explanatory variables. Chisquare test was also used to assess the association of households and farm-related characteristics between groups (diversifier vs. non-diversifier). Moreover, to investigate the determinants of rural household decisions and extent of crop diversification, double hurdle model was used.

\section{Empirical model Specification}

There are various methods to measure crop diversification (Magurran, 1988; Malik et al., 2002). The current study used Herfindahl Index (HI) as measures of crop diversification to represent relative land sizes of farming activities operated by a given farm, widely used in crop diversification literature (Magurran, 1988; Malik et al., 2002; Sichoongwe et al., 2014). The CDI (Crop Diversification Index) has a direct relationship with crop diversification, such that a zero value implies specialization and a value greater than zero means crop diversification. The CDI is obtained by subtracting the Herfindahl index (HI) from one (1-HI). Precisely, the $\mathrm{CDI}$ is calculated as follows:

$$
p_{i}=\frac{A_{i}}{\sum_{i=1}^{n} A_{i}}
$$

2

where, $\mathrm{P}_{\mathrm{i}}=$ proportion of $\mathrm{i}^{\text {th }}$ crop, $\mathrm{A}_{\mathrm{i}}=$ Area under $\mathrm{i}^{\text {th }} \operatorname{crop}(\mathrm{ha})$,

$\sum_{\mathrm{i}=1}^{\mathrm{n}} \mathrm{A}_{\mathrm{i}}$ totalcropland(ha)andi $=1,2,3 \ldots, \mathrm{n}$ (numberofcrop)

HerfindahlIndex $=\mathrm{HI}=\sum_{i=1}^{n} p_{i}^{2}$ (3) Cropdiversificationindex $=C D I=1-H I(4)$

The analysis of crop diversification entails a situation where at each observation the event may or may not occur. An occurrence (crop diversification) is associated with a continuous non-negative random variable, while a non-occurrence (not diversifying) yields a variable with zero value (Cragg, 1971). Such a scenario presents a limited dependent-variable (Engel et al., 2014) modeling problem where the lower bound of the variable, zero value, occurs in a considerable number of observations. The occurrence of the event allows a continuous distribution over positive values, but an "accumulation" at zero exists (due to non-occurrence), which is a corner solution for the diversification problem (García, 2013). Such common cases in the social sciences invalidate the use of the usual regression model and require models capable of handling binary endogenous variables. 
The common approaches of modeling such situations include the Tobit, Heckman and double-hurdle models (Komarek, 2010).Several studies have applied the Tobit model to approach this type of study (Bellemare and Barrett, 2006; Gebremedhin and Jaleta, 2010; Martey et al., 2012; Gani and Adeoti, 2014), but the major drawback of this approach is that it imposes a restriction that both diversification decisions are simultaneously influenced by the same set of explanatory variables (Ground and Koch, 2008). Since we assume, in this study, that the decisions on crop diversification and level of diversification are influenced by different sets of independent variables, the Tobit model is not recognized. It is also argued that the model yields biased parameter estimates (Wanyoike et al., 2015) and recent studies have stressed the inadequacy of the Tobit, proposing the use of less restrictive alternative approaches to Heckman's model (Heckman 1979) and Cragg's double obstacle model (Cragg 1971). These two-step alternative models are relevant for our study because separate vectors of independent variables influence the farmer's crop diversification decision.

The double hurdle is a less restrictive variant of the Heckman and is best suited for samples drawn through random probabilistic sampling procedures (Komarek, 2010). Therefore, the double hurdle was adopted for the analysis of our randomly selected sample data. The model is a generalization of Tobit, where two distinct stochastic processes determine participation and quantitative decisions. The remarkable difference between the two-step models is based on the contribution of the Heckman, which non-participants will not participate under any circumstance (Kiwanuka and Machethe, 2016). Contrary, the double hurdle assumes that the decision not to participate is a deliberate choice (Tura et al., 2016), then the zeros of the nonparticipants are considered as the solution of the angles in the utility maximization model (Yami et al., 2013).The model is also flexible, assuming that there are no restrictions on the components of the independent variables in each phase of estimation.

The double hurdle model is more flexible than the Tobit and allows the participation and extent of crop diversification to be determined separately (Burke, 2009). The model requires a joint application of the probit and truncated regression models, sequentially or simultaneously (Yami et al., 2013). The theoretical basis of the double-hurdle estimation framework by Cragg (Cragg, 1971) is grounded on the probit model where the probability of crop diversification at observation $t, p\left(E_{t}\right)$, is given by:

$$
P\left(E_{t}\right)=\int_{-\infty}^{x^{\prime} \beta}(2 \pi)-\frac{1}{2} \exp \left\{-z^{2} / 2\right\} d z
$$

7

Where $X_{t}$ is a $K^{\star} 1$ vector of exogenous variables at observation $t$ and $\beta$ represents a vector of parameter estimates. Then the cumulative unit normal distribution is designated as

$$
C(z)=\int_{-\infty}^{z}(2 \pi)-\frac{1}{2} \exp \left\{-t^{2} / 2\right\} d t
$$

8

The probit model estimates the probability of a farmer to participate in crop diversification (first diversification decision). The second quantity of diversification occurs when favorable circumstances 
(search, information and transaction costs) prevail to allow the diversification to be completed (Moffatt, 2005). This non-negative quantity decision can only be measured for non-zero values in the first decision, thus estimated by the truncated regression (Ground and Koch, 2008). Therefore, the double-hurdle twoequation framework (Mathshe and Young, 2004 ;) Kefyalew, 2012) is presented as:

$$
C D_{i}^{*}=z_{i}^{*} \alpha+\varepsilon_{i} \text { Diversification Decision } Q^{C D *}=X_{i}^{\prime} \beta+\mu_{i} \text { Quantity Diversified }\left(\begin{array}{c}
\varepsilon_{i} \\
\mu_{i}
\end{array}\right) \sim N\left[\left(\begin{array}{ll}
0 \\
0
\end{array}\right)\left(\begin{array}{ll}
1 & 0 \\
1 & \partial^{2}
\end{array}\right)\right]
$$

Where $C D_{i}^{*}$ is the latent variable for the binary dependent variable taking a value of one for crop diversification and zero indicates otherwise. $Q^{C D * *}$ is the latent variable reflecting the number of crop diversified. $z_{i}^{*}, \alpha a n d \epsilon_{i}$ represent vectors of explanatory variables, parameter estimates and the error term for the crop diversification decision. Likewise, $X_{I}^{\prime} \beta$ and $\mu_{i}$ represent vectors of explanatory variables, parameter estimates and the error term for the level of crop diversification. Since an individual farmer is involved in both sales decisions, the error terms are assumed to be independently and normally distributed, thus the first hurdle corresponds to a probit model (Kefyalew, 2012).

The binary dependent variable of the diversification decision in Equation (9) is defined by

$$
C D_{i}^{*}=1 \text { ifCD } D_{i}^{*}>0, C D_{i}^{*}=0 \text { ifCD } D_{i}^{*} \leq 0(10)
$$

and decisions on the level of crop diversification is defined by

$$
Q^{C D *}=\max \left(Q^{* *}, 0\right)
$$

11

The observed variable, $Q^{C D *}$ (normally presented as $y_{i}$ in literature) is determined as

$$
Q_{i}^{C D *}=C D_{i} Q_{i}^{C D *}
$$

12

and log-likelihood function for the double hurdle is:

$$
\log L=\sum_{0} \ln \left[1-\Phi\left(z_{i}^{\prime}\right) \Phi\left(\frac{X_{i}^{\prime} \beta}{\sigma}\right)\right]+\sum_{+} \ln \left[\Phi\left(z_{i}^{\prime}\right) \frac{1}{\sigma} \Phi\left(\frac{y_{i-}^{\prime} X_{i}^{\prime} \beta}{\sigma}\right)\right]
$$

13

\section{Variables Definition}

There are a number of studies that identify level and determinants of crop diversification at different level. Reviewed literature indicates that the decision and extent of crop diversification practices depend on demographic, socioeconomic, farm attributes, and institutional factors. These factors include sex, age, 
family size, education level, size of livestock holding, amount of off/non-farm-income, farm experience, farm size, land fragmentation, plot fertility, access to credit, extension services, distance to nearest market and cooperative membership. The list of explanatory variables used in the Cragg's double hurdle model and their expected signs are summarized in Table 1. 
Table 1

Summary of the explanatory variables used in double hurdle model

$\begin{array}{ll}\text { Variables Measurement } & \begin{array}{l}\text { Expected } \\ \text { sign }\end{array}\end{array}$

\section{Dependent Variable}

Crop Diversification Indices

\section{Explanatory Variables}

Gender

Age of household head

Family size

Labor availability

Education level of household

Farm experience

Access to Credit

Extension visit

Cooperative member

TLU

Farm land size

Plot fertility

Number of plots

Distance to market

Distance to FTC

Distance to Farm

Income (annual income)

Number of oxen

Participation on off/non-farm income
Index

Sex of household head (Male $=1$, female $=0) \quad-+$

Age of household head (years)

$-+$

Persons in the household(Number)

Access to labor for farming (yes $=1, \mathrm{No}=0$ )

In year of schooling

Number of year engaged in farming activities

Access to credit (Yes $=1, \mathrm{No}=0$ )

$+$

$+$

$+$

$+$

$-+$

Frequency of Extension contact (Frequency) +

Membership to farmers' cooperative (Yes=1, - $\quad-$ $\mathrm{No}=0$ )

Size of Livestock owned (TLU)

$+$

Land operated for farming by the household(ha) +

Plot fertility (Yes $=1, \mathrm{No}=0)$

$-+$

Number of plot operated for farming (number) +

Distance from homestead to nearest market $(\mathrm{km}) \quad$-+

Distance from homestead to FTC $(\mathrm{km})$

$-+$

Distance from homestead to farm $(\mathrm{km})$

Total income (birr)

$+$

Number of oxen used for farming (Number) +

Participation on off/nonfarm activities (yes $=1, \quad-/+$ $\mathrm{No}=0$ )

+ indicates listed variables were expected to affect crop diversification negatively or positively

\section{Result And Discussions}

Household Characteristics and Status of Crop Diversification 
The finding indicates that 58.72 percent of rural households in study area did not diversify cropping systems. Further, using the Hirschman and Albert (1964) formula, the study found that the average CDI of sampled households is 41.28 percent. This implies that the cropping system is less diverse. Table 2 shows descriptive analyses that aim to give a picture of demographic and socio-economic characteristics of the diversifier and non-diversifier farmers in the study area.

The survey result shows that two third of the respondents were male-headed households while the remaining one third were female-headed households. The average family size of household was 7.06 with standard deviation of 2.24 .

Most of the crop diversifier and non-diversifier households in the study area (88.78 and 81.43 percent, respectively) had not received credit. Only 2.63 percent of crop diversifiers and 6.44 percent of nondiversifiers were visited by extension agents in the study area. The finding also indicates that most of rural households ( 66.67 percent of crop diversifiers and 74.29 percent of non-diversifier) were members of farmers' cooperatives.

The results of the survey showed that 82.77 percent of household heads have no education. The remaining 17.23 percent attend different educational levels, i.e. primary school at 15.44 percent, secondary school at 1.57 percent, and university or college at 0.52 percent. The average years of farm experience of household head is 24.74 years with standard deviation of 8.68. Education level and farm experience of household head determine crop diversification because educated and farmers with more farm experience easily understand agricultural instructions provided by the extension workers.

Findings of the study showed that almost all sampled households own livestock though the number of livestock varies. The mean livestock holding in Tropical Livestock Unit (TLU) for the sample households is 7.48. Non-diversifier households have a better livestock holding than the diversifier households. The mean livestock holding in TLU for crop diversifier households is 7.53 and 8.10 for non-diversifiers.

Regardless of the size, all respondents have ensured that they own land they operate. The landholding of the sample households ranges from 0.5 ha to 9 ha. The average land holding is 2.99 ha. The mean landholding for crop diversifiers is $2.77 \mathrm{ha}$, and the corresponding figure for non-diversifiers is $3.14 \mathrm{ha}$. The survey results indicate that the mean number of farm plots that farmers own is 3.13. The mean farm plots for crop diversifiers are 1.82; the corresponding figure for non-diversifiers is 3.27 farm plots. Findings of the survey results indicates that 49.87 percent of households have fertile plots. The comparison between crop diversifiers and non-diversifiers showed that 29.11 and 52.10 percent of the households perceived that they have infertile land. (Table 2).

Household labor is the availability of economically active age groups that are ranging between 15 and 64 . Availability of this age group helps households to diversify their livelihoods into various cropping systems, and hence easily assure their food need. The availability of household active labor has important role in the crop diversification. Households who did not have sufficient labor, especially for agricultural purpose would be forced to hire labor. 
Table 2

Descriptive result of factors affecting crop diversification

\begin{tabular}{|c|c|c|c|c|}
\hline Characteristics & $\begin{array}{l}\text { Non-Diversified \% or } \\
\text { mean } \\
\left(n_{1}=71\right)\end{array}$ & $\begin{array}{l}\text { Diversified \% or } \\
\text { mean } \\
\left(n_{2}=311\right)\end{array}$ & Total & $\begin{array}{l}\chi^{2} \text { or } t \\
\text { test }\end{array}$ \\
\hline $\begin{array}{l}\text { Gender of household head (\% } \\
\text { female) }\end{array}$ & 12.86 & 14.57 & 11.54 & 0.006 \\
\hline Age of $\mathrm{HH}$ & 44.47 & 44.23 & 44.33 & $-0.003^{\star \star}$ \\
\hline Family size in number & 6.69 & 7.13 & 7.06 & 0.010 \\
\hline Labor availability (\%yes) & 47.25 & 75.56 & 63.34 & $.0405^{\star \star}$ \\
\hline Education level of household head & 0.34 & .37 & .362 & $0.002^{\star \star}$ \\
\hline Farm Experience in year & 35.61 & 24.72 & 24.74 & $0.011^{* \star *}$ \\
\hline Use of credit (\% yes) & 18.57 & 11.22 & 12.50 & 0.024 \\
\hline $\begin{array}{l}\text { Livestock holding in total livestock } \\
\text { unit/TLU }\end{array}$ & 7.24 & 7.57 & 7.48 & -0.002 \\
\hline Farm land size & 2.67 & 3.06 & 2.99 & $-0.007 * \star \star$ \\
\hline Number of Plot & 2.64 & 3.22 & 3.13 & $0.001^{* \star}$ \\
\hline Plot Fertility/Average (\% poor) & 97.14 & 61.22 & 49.87 & $0.092^{*}$ \\
\hline Extension Visit (\% yes) & 94.29 & 95.51 & 95.05 & $0.097 \star \star$ \\
\hline Membership to Coops (\% yes) & 74.29 & 66.67 & 67.97 & $-0.016^{\star \star}$ \\
\hline Distance to Market & 26.29 & 30.03 & 29.33 & 0.003 \\
\hline Distance to FTC & 15.66 & 15.93 & 15.87 & 0.003 \\
\hline Distance to Farm & 15.96 & 15.73 & 15.77 & -0.004 \\
\hline Total Income/AE in birr & 5214.29 & 7370.19 & 6943.18 & $2.76 \mathrm{e}-06$ \\
\hline Number of Oxen & 2.39 & 2.37 & 2.68 & 0.061 \\
\hline
\end{tabular}

Factors influencing smallholder farmers decision to crop diversification

This result presented in (Table 2) shows that overall, the model is statistically significant at the $<0.1$ with Wald test Wald $\chi^{2}(18)=231.19$, Pseudo $R^{2}=1.0294$ and log likelihood $=3.3021182$, which indicates that the model fulfilled the condition of good fit. Multicollinearity was checked using variance inflation factor (VIF) and the calculated VIF values are all less than ten (the cut-off point), which indicated that multicollinearity is not a problem. A test for normality of CDI was made using Kernel density plot residuals. Was completed the usage of the kernel density plot of residuals. The kernel density plot supplied a 
reasonably clean curve that closely resembles a normally distributed curve, indicating that the normality assumption was not violated (Figure 2).

The coefficient of age of household head is negative and significant at ten percent, indicating an inverse relationship between age of household head and decision to crop diversification. The result indicates that a one-year increase in age of household reduces the probability of crop diversification by 0.3 percent. Elderly farmers were less likely to participate in crop diversification and probably are engaging only in food crop production. The reason is that older farmers cannot manage the farm properly and usually rely on old farming systems. In addition, this can also imply that families with more workers are more subject to the risk of work. This agrees with the findings of Ojo et al. (2014) and Lighton et al. (2016), who also found that a farmer's risk-bearing ability reduces as his/her age increases.

Farm size has a negative significant effect on probability of crop diversification at one percent level of significance. The negative impact of farm size suggests that farmers with relatively small farm practice crop diversification than large farms. This is in agreement with our hypothesis formulated regarding the relationship between crop diversification and land holding size of the household. On average, each additional hectare of land decreases the probability of farmer crop diversification by 25.4 percent. Similar to this, studies by Assefa and Gezahegn (2010) and Moti et al. (2013) found a similar result.

Plot fertility is significant at $p<0.01$, reflecting that holding of infertile plot decrease probability of crop diversification. The study further revealed farmers with access to fertile farm plots are $4.33 \%$ less likely to diversify their agricultural production than farmers who have access to fertile agricultural land. The negative coefficient for the number of fertile plots owned and operated by a household indicates that households with fertile farm plots are less likely to diversify by growing different crops. We surmise that if the soils are productive, the farmer will have more cropping options and is probably to participate in more than one crop enterprise on the farm. Farmers with low soil fertility farms are more likely to adopt diversified crop rotations as they have been shown to contribute to higher and more stable net farm income when compared to traditional monoculture, which over extended periods of time, has shown evidence of degradation of soil quality and reduced crop productivity (Clark, 2004).

It appears a positive and significant relationship between frequency of extension contacts per year and crop diversification and the coefficient is significant at $<0.01$. This might be associated with the extension system, which is focused on enhancing farmers' productivity and profitability. Extension service providers favor crop diversification at the micro level and are generally aware of the role of crop diversification in risk minimization. We found that access to extension services increases the probability of a farmer's participation in crop diversification by 50.36 percent. The result is consistent with the findings of Mesfin, Fufa, and Haji, (2011); Rehima et al. (2013); Sisay, (2016), and Asante et al. (2017), where a positive relationship was found between probability of crop diversification of the household and their access to extension services.

Participation in off/non-farm activities negatively and significantly affects probability of crop diversification at five percent probability level. In those households that participated in off/non-farm activities, the likelihoods of farmers participating in crop diversification decreases by 20.70 percent. The plausible 
explanation is that if a household receives income from off-farm work, it is less likely to pursue crop diversification as a method of reducing financial risk associated with farming (Sandretto et al., 2004). This finding is similar with findings of Lighton and Emmanuel (2016) and Dessie et al. (2019), who also found out that off-farm income had a significant and negative effect on crop diversification.

Table 3

Probit regression estimates for determinants of crop Diversifications

\begin{tabular}{|llll|}
\hline Variables & Coeff. & Std. Err. & Marginal Effect \\
\hline Gender & -0.022 & 0.026 & 0.002 \\
\hline Age of household head & $-0.003^{* \star *}$ & 0.001 & -0.003 \\
\hline Household size & 0.004 & 0.004 & 0.008 \\
\hline labor used & -0.003 & 0.017 & 0.050 \\
\hline Education level of household head & 0.001 & 0.011 & -0.007 \\
\hline TLU & -0.002 & 0.002 & -0.005 \\
\hline Farm land size & $-0.442^{*}$ & 0.104 & 0.254 \\
\hline Number of plots & -0.007 & 0.005 & 0.005 \\
\hline Plot fertility & $0.119 *$ & 0.009 & -0.046 \\
\hline Extension visit & $0.086^{* *}$ & 0.041 & 0.081 \\
\hline Remittance & 0.011 & 0.018 & 0.089 \\
\hline Distance to nearest market & -0.001 & 0.001 & 0.006 \\
\hline Distance FTC & 0.003 & 0.003 & 0.006 \\
\hline Distance to farm & 0.002 & 0.003 & -0.012 \\
\hline Number of oxen & 0.012 & 0.008 & 0.002 \\
\hline Participation in off/non-farm activities & $-0.037 * *$ & 0.018 & -2.070 \\
\hline - cons & 0.856 & 0.137 & -1.220 \\
\hline LR Chi (18) =231.19 & & & \\
\hline Number of Observations =383 & & & \\
\hline Prob > chi2= 0.0000 & & & \\
\hline Pseudo R2=1.0294 & & & \\
\hline * ** and *** significant at 1\%, 5\% and 10\% significance level respectively \\
\hline
\end{tabular}

Factors influencing the extent of Crop Diversification 
Ceteris paribus, the statistically significant variables allude to an increase or decrease in the extent of crop diversification, subject to the sign of the relevant parameter estimate (see Table 2.4). The key factors affecting the level of crop diversification that reveal statistical significance at $p<0.01$ include farm land size, plot fertility, extension visits, distance to nearest market, distance to farm, and total annual income.

Table 4

Truncated regression estimates for determinants of level of crop diversification

\begin{tabular}{|c|c|c|c|}
\hline Variables & Coeff. & Std. Err & Marginal Effect \\
\hline Gender & 0.009 & 0.256 & -0.019 \\
\hline Age of household head & -0.011 & 0.009 & -0.003 \\
\hline Household size & 0.033 & 0.042 & 0.008 \\
\hline labor used & 0.217 & 0.152 & 0.025 \\
\hline Education level of household head & -0.029 & 0.107 & -0.004 \\
\hline Livestock Holding & $-0.023^{*}$ & 0.024 & -0.004 \\
\hline Farm land size & $1.097^{\star \star \star}$ & 0.637 & 0.209 \\
\hline Number of plots & 0.022 & 0.050 & -0.002 \\
\hline Plot fertility & $-0.200 * \star$ & 0.102 & 0.073 \\
\hline Extension visit & $0.385^{\star \star}$ & 0.184 & 0.048 \\
\hline Remittance & 0.349 & 0.365 & 0.115 \\
\hline Distance to nearest market & $0.024^{\star}$ & 0.009 & 0.002 \\
\hline Distance FTC & 0.026 & 0.030 & 0.005 \\
\hline Distance to farm & $-0.053^{\star \star}$ & 0.028 & -0.005 \\
\hline Total annual income & $0.013^{\star}$ & 0.07 & 0.010 \\
\hline Number of oxen & 0.007 & 0.081 & 0.010 \\
\hline Access to Remittance & $0.343^{\star \star \star}$ & .183 & .048 \\
\hline _cons & -1.249 & 1.025 & \\
\hline
\end{tabular}

The coefficient of livestock ownership is negative and significant at one percent indicating an inverse relationship between livestock ownership and extent of crop diversification. The results indicate that a one unit increase in TLU among rural households decreased the level of crop diversification by 2.3 percent. The explanation for the result is that livestock as a measure of wealth may act as insurance against crop production risk, bearing a negative relationship with crop diversification. So, households with large number 
of livestock are less likely to grow more crops. The result is consistent with the findings of Benin et al. (2004), but in contrast to that of Fetien, Asmund, and Melinda (2009).

The amount of land owned by the farmer has a positive and significant effect on the extent of crop diversification at ten percent level of significance. This indicates that an addition of one hectare of land increases the extent of diversification by 20.9 percent. This implies that large farm size may enable households to allot their land for multiple crops, thereby, minimize income, production and price risks than small land holders. The result supports the finding of Benin et al. (2004), Fetien et al. (2009), Wondimagegn et al. (2011) and Rehima et al. (2013). They found a positive relationship between the level of crop diversification and total farm size in their respective studies.

The coefficient of fertile plot/plot fertility has significantly and negatively affected extent of crop diversification at five percent level of significance. Households that had access to fertile farm plots decreased their levels of diversification by 7.03 percent. This implies that fertile land is promising to increase production and yield, and the households might have motivated to produce a more profitable crop because they can easily increase production and yield levels. This is consistent with the findings of Rehima (2013) and Lighton and Emmanuel (2016), who also found that a fertile plot had a significant and negative effect on crop diversification.

Extension service (frequency of contacts) has positively and significantly affected the extent of crop diversification practice at five percent level of significance. This implies that extension workers have an important role to play in creating awareness among farmers as well as educating them on the importance of diversification. A household who had more frequency of extension contact during the cropping period increased probability of being engaged in crop diversification practice by 4.8 percent. This finding is consistent with the research results of Ibrahim et al. (2009) and Rehima et al. (2013).

The coefficient of walking distance from residence to the nearest market significantly and positively affected extent of crop diversification at less than one percent significance level. An increase in one minute to walk to the nearest market increased the extent of crop diversification of households by 0.2 percent. The possible explanation is that the households that have poor market access are more likely to rely on diversification to meet their consumption needs and to avoid transaction costs. The finding concurs with Alpízar (2007), Rahima et al. (2013), and Dessie et al. (2019) indicating a household far from a market was positively related to crop and variety diversification.

Walking distance from residence to the farm plot significantly and negatively affected extent of crop diversification at less than ten percent level of significance. As walking to the farm plot increases by a minute, the extent of crop diversification of households decreased by 0.50 percent. This finding is similar with the finding of Benin et al. (2004) and Sichoongwe et al. (2014), who indicated households living farther from their farms manage fewer crop diversity.

The coefficient of total annual income positively and significantly affected extent of crop diversification at less than one percent level of significance. We found out that a one Birr increase in income increased the extent of crop diversification by 1.00 percent. This implies that higher incomes allow farmers to have access 
to critical productive resources such farm assets, inputs, and land, which increase the extent of crop diversification. The extra income earned by farmers from one crop is also important in providing financial resources that are used for diversification into other crops. Similar studies by Bonham et al. (2012), Rehima et al. (2015), and Basantaray and Nancharaiah (2017) indicated that crop diversification is strongly associated with higher farm income.

\section{Conclusion And Recommendations}

The objective of this study was to analyze crop diversification among wheat-dominant producer rural households. Crop diversification was measured by Herfindahl-Hirschman Index, while double hurdle model was used to identify probability and extent of crop diversification in study area. The study found that the average CDI of sampled households was 41.28 percent. The results also revealed that age of household head and participation in off/non-farm activities negatively influence probability of crop diversification, while household size, access to fertile plots of land, and access to extension services positively influence probability of crop diversification in study area. The results further showed that labor availability, distance to nearest market, total annual income, and membership to farmers' cooperatives positively influence extent of crop diversification. In contrast, distance to farm plots, access to fertile plots of land, and TLU negatively affect extent of crop diversification in study area.

Access to extension services significantly and positively affect likelihoods of crop diversification practices. Given the positive effects of access to extension services on crop diversification, there is now a strong need to strengthening available extension packages to help smallholder farmers improve probability of crop diversifications. Hence, the local government should arrange experience-sharing and short-term training programs so as to share the rich knowledge to inexperienced farmers.

Membership to farmers' cooperatives significantly and positively affect extent of crop diversification practices. Thus, we recommend that efforts must be made to strengthen the role of farmers' cooperatives in information dissemination, farmer-to-farmer extension, and smallholder farmers' access to markets and their bargaining power for higher producer prices.

Household size (labor supply) positively and significantly affects likelihoods of crop diversification. The results also indicated that the availability of labor positively and significantly affects the extent of crop diversification in the study area. The results suggested that policy and strategy makers should consider availability of labor force before introducing labor-intensive technology in other similar agro-ecology areas of the country. As the same time, regional and local governments should encourage the use of labor-saving technologies in diversified farming systems.

To this end, the findings suggest that policies that target achieving food and nutritional gains should focus on promoting crop diversification to improve the quality and variety of the products from own farming. These needs supporting farmers through subsidy and providing access to reliable price information and inputs. Integrating diversification strategies into the extension system of the country could also help promote diverse production systems that feature cereals, cash crops, and legumes. 
The study did not consider crop production efficiency nor the role of gender in crop diversification. Future research should focus on understanding the association that exists between crop diversification and household crop production efficiency that could impede productivity. To address this knowledge gap, further research is needed to determine the optimum number and combination of crops and income that the household can efficiently manage without compromising the benefits of crop diversification.

\section{Abbreviations}

Agricultural Development Led Industrialization: ADLI; Bale Zone Agriculture Development Organization: BZADO; Bale Zone Finance and Economic Development: BZFED; Crop Diversification Index: CDI; Focus Group Discussions: FGDs; Gross Domestic Product: GDP; Growth and Transformation Plans: GTPs; Herfindahl Index: HI; Inverse Mill's Ratio: IMR; Key Informant Interviews: KIls; Ordinary Least Square: OLS; Tropical Livestock Unit: TLU

\section{Declarations}

\section{Ethics approval and consent to participate}

The researchers have obtained a support letter from Addis Ababa University. The letter was submitted to Bale Zone Agriculture and Natural Resource Office and obtained consent. Then, the zonal offices have written an official letter to Sinana District Agriculture and Natural Resource Office where the study was conducted. Informed consents were also obtained from the households, discussants, and informants before data collection in conformity with anonymity of the study participant.

\section{Consent for publication}

Not applicable

\section{Availability of data and materials}

The authors want to declare that they can submit the data at whatever time based on your request. The datasets used and/or analyzed during the current study will be available from the corresponding author on reasonable request.

\section{Competing interests}

The authors declare they have no competing interests.

\section{Funding}

This research was supported and funding by Addis Ababa University.

\section{Authors' contributions}


DD designed the study, collected the data, performed the analysis, and developed the manuscript. DT and AS contributed to the research design and analysis, reviewed and made editorial comments on the draft manuscript. All authors read and approved the final manuscript.

\section{Acknowledgements}

The authors acknowledge respondent farmers and data collectors. Addis Ababa University, Madda Walabu University were also acknowledged for their financial and logistical support in accomplishing this paper. The authors also would like to extend their deep thanks to all the contributors of this study, namely local administrators, and development agent workers who took part in the survey.

\section{References}

1. Acharya SP, Basavaraja LB, Kunnal SB, Mahajanashetti, Bhat AR. Crop Diversification in Karnataka: An Economic Analysis. Agricultural Economics Research Review, 2011; 24, 351-357.

2. Adjimoti GO, Kwadzo GT, Sarpong D B, Onumah EE. Input policies and crop diversification: Evidence from the Collines Region in Benin. African Development Review, 2017; 29(3), 512-523.

3. Ainembabazi JH, Mugisha J. The role of farming experience on the adoption of agricultural technologies: Evidence from smallholder farmers in Uganda. Journal of Development Studies, $2014 ; 50$ (5), 666-679.

4. Alpizar C. Risk coping strategies and rural household production efficiency: quasi experimental evidence from El Salvador. 2007. (Electronic Thesis or Dissertation). Retrieved from https://etd.ohiolink.edu/

5. Asante BO, Rene AV, George B, Lan P. Determinants of farm diversification in integrated crop-livestock farming systems in Ghana. Renewable Agriculture and Food Systems, 2017; 33(2), 131.

6. Ashfaq MS, Hassan MZ, Naseer IA, Baig J, Asma J. Factors affecting farm diversification in rice-what. Pak. J. Agri. Sci. 2008; 45(3), 91-94.

7. Baba AR, Abdulai AM. Determinants of Crop Diversification and Its Effects on Household Food Security in Northern Ghana. Journal of Economic Theory and Practice. 2020; https://doi.org/10.1177/0976747920936818

8. Barretta CB, Reardon T, Webb P. Nonfarm income diversification and household livelihood strategies in rural Africa: concepts, dynamics, and policy implications. Food Policy, 2001; 26 (4), 315-331

9. Basantaray AK, Nancharaiah G. Relationship between Crop Diversification and Farm. Agricultural Economics Research Review, 2017; 30, 45-58.

10. Bellemare MF, Barrett CB. An ordered Tobit model of market participation: Evidence from Kenya and Ethiopia. Am. J. Agric. Econ., 2006; 88, 324-337.

11. Benin S, Smale M, Gebremedhin B, Pender J, Ehui S. The determinants of cereal crop diversity on farms in the Ethiopian Highlands. Contributed paper for the 25th International Conference of Agricultural Economists, Durban, South Africa. 2004; https://doi.org/10.1016/j.agecon.2004.09.007 
12. Block S, Timmer P. Agriculture and economic growth: conceptual issues and the Kenyan experience. 1994; Development Discussion Paper No. 498. Cambridge, MA, USA.

13. Bonham CA, Gotor E, Beniwal BR, Canto GB, Ehsan, MD, Mathur P. The patterns of use and determinants of crop diversity by pearl millet (Pennisetum glaucum (L.) R. Br.) Farmers in Rajasthan. Ind J Plant Genet Resour, 2012; 25(1), 85-96

14. Burke WJ. Fitting and interpreting Cragg's Tobit alternative using Stata. Stata J. 2009; 9, 584-592.

15. BZSP (Bale Zone Socio-Economic Profile). Bale-Zone Culture and Tourism office. 2011; Robe-Bale, Ethiopia

16. BZSP (Bale Zone Socio-Economic Profile). Bale-Zone Agriculture and Natural Resource Office. 2015; Robe-Bale, Ethiopia

17. Clark D. Sustainable Maize Production-Crop Rotation. 2004; Foundation for Arable Research (New Zealand).

18. Conley G, Udry, C. Learning About a New Technology: Pineapple in Ghana. The American Economic Review, 2010; 100(1), 35-69. https://doi.org/10.1257/aer.100.1.35

19. Cragg JG. Some statistical models for limited dependent variables with application to the demand for durable goods. Econometrica, 1971; 39, 829-844.

20. Davis B, Di Giuseppe S, Zezza A. Income diversification patterns in rural Sub-Saharan Africa: reassessing the evidence. World Bank Policy Research Working Paper No. 7108. 2014; Washington DC: World Bank. https://doi.org/10.1596/1813-9450-7108

21. Davis T, Schirmer J, Isabelle A. Sustainability issues in agricultural development, Proceedings of seventh Agriculture Sector Symposium. 1987; World Bank, Washington DC.

22. De Janvry A, Fafchamps $M$, Sadoulet E. Peasant household behavior with missing markets: some paradoxes explained. Economic Journal, 1991; 101(409), 1400-1417.

23. Degye G, Belay K, Mengistu K. Does Crop Diversification Enhance Household Food Security? Evidence from Rural Ethiopia. Advances in Agriculture, Sciences and Engineering Research, 2012; 2 (11), 503515.

24. Dessie AB, Abate TM, Mekie TM. Crop diversification analysis on red pepper dominated smallholder farming system: evidence from northwest Ethiopia Ecological Processes. 2019; 8:50.

25. Dillon B, Barret CB. Agricultural factor markets in Sub-Saharan Africa: An updated view with formal tests for market failure. Food Policy, 2017; 67, 64-77.

26. Eisenhauer N. Plant diversity effects on soil microorganisms: spatial and temporal heterogeneity of plant inputs increase soil biodiversity. Pedobiologia. 2016; 59 (4): 175-177.

27. Ellis F. Peasant Economics: Farm household and agrarian development. 1993.Cambridge University Press, UK.

28. Ellis F. The determinants of rural livelihood diversification in developing countries. Journal of Agricultural Economics, 2000; 51(2), 289-302. https://doi.org/10.1111/j.1477-9552.2000.tb01229.x

29. Engel C, Moffatt PG, Dhreg X, Bootdhreg. Commands to implement Double Hurdle Regression. Stata J. $2014 ; 14,778-797$. 
30. Fafchamps M. Cash Crop Production, Food Price Volatility, and Rural Market Integration in the Third World. American Journal of Agricultural Economics, 1992; 74(1) 90-99.

31. FAO, IFAD, UNICEF, WFP, WHO. The State of Food Security and Nutrition in the World. Building resilience for peace and food security. 2017; Rome, FAO

32. FAO. Human Energy Requirements: FAO Food and Nutrition Technical Report Series 1. 200; Rome-Italy

33. FAO. Crop diversification for sustainable diets and nutrition: The role of FAO's Plant Production and Protection Division: 2012; Technical report Plant Production and Protection Division, Food and Agriculture Organization of the United Nations, Rome

34. FAO. Pulse contribution to Food Security: International Pulse Day. 2016; Rome-Italy

35. Feliciano D. A review on the contribution of crop diversification to Sustainable Development Goal 1 "No poverty" in different world regions. Sustainable Development. 2019; 27, 795-808.

36. Fetien A, Bjornstad A, Smale M. Measuring on farm diversity and determinants of barley diversity in Tigray, northern Ethiopia. MEJS, 2009; 1(2), 44-66.

37. Francesco G. Agricultural Diversification and Rural Industrialization as a Strategy for Rural Income Growth and Poverty Reduction in Indochina and Myanmar. 1999; Markets and Structural Studies Division, International Food Policy Research Institute, 2033 K Street N.W. Washington, D.C.

38. Gani B, Adeoti A. Analysis of market participation and rural poverty among farmers in northern part of Taraba State, Nigeria. J. Econ. 2011; 2, 23-36.

39. García B. Implementation of a Double-Hurdle Model. Stata J. 2013; 13, 776-794.

40. Gebremedhin B, Jaleta M. Commercialization of smallholders: Is market participation enough? 2010; In Proceedings of the Joint 3rd African Association of Agricultural Economists (AAAE) and 48th Agricultural Economists Association of South Africa (AEASA), Cape Town, South Africa, 19-23 September 2010.

41. Ground M, Koch SF. Hurdle models of alcohol and tobacco expenditure in South African households. $S$. Afr. J. Econ. 2008; 76, 132-143.

42. Heckman JJ. Sample selection bias as a specification error. J. of Econometrica, 1979; 47(1),153-162.

43. Hirschman O, Albert O. The paternity of an index. Journal of American Economic Review, 1964; 54(5): 761.

44. Hitayezu P, Zegeye EW, Ortmann GF. Farm-level crop diversification in the Midlands region of KwazuluNatal, South Africa: patterns, microeconomic drivers, and policy implications. Agroecology and Sustainable Food Systems, 2016; 40 (6), 553-582.

45. Kanyua MJ, Ithinji GK, Muluvi AS, Gido OE, Waluse SK. Factors influencing diversification and intensification of horticultural production by smallholder tea farmers in Gatanga District, Kenya. Current Research Journal of Social Sciences, 2013; 5(4), 103-111.

46. Kassie M, Jaleta M, Shiferaw B, Mmbando F, Mekuria M. Technological Forecasting and Social Change Adoption of interrelated sustainable agricultural practices in smallholder systems: Evidence from rural Tanzania. Technological Forecasting \& Social Change, 2012; 80(3), 525-540. 
47. Kassie M, Shiferaw B, Geoffrey M. 2011 Agricultural technology, crop income, and poverty alleviation in Uganda. World Development.2011; 39(10), 1784-1795.

48. Kefyalew G. Analysis of Smallholder Farmer's Participation in Production and Marketing of Export Potential Crops: The Case of Sesame in Diga District, East Wollega Zone of Oromia Regional State. Master's Thesis, Addis Ababa University, Addis Ababa, Ethiopia, 2012.

49. Kiwanuka RN, Machethe $C 2016$. Determinants of smallholder farmers' participation in Zambian dairy sector's interlocked contractual arrangements. J. Sustain. Dev. 2016; 9, 230-245.

50. Komarek A. The determinants of banana market commercialization in Western Uganda. Afr. J. Agric. Res.2010; 5, 775-784.

51. Kurosaki T. Specialization and Diversification in Agricultural Transformation: The Case of West Punjab, 1903-1992. American Journal of Agricultural Economics. 2003; 85(2).

52. Lighton D, Emmanuel G. Factors Influencing Smallholder Crop Diversification: A Case Study of Manicaland and Masvingo Provinces in Zimbabwe. International Journal of Regional Development, 2016; 3(2), 2373-9851.

53. Maddala GS. Limited dependent and qualitative variables in economics. Cambridge UK, Cambridge University Press. 1999; pp. 1-231.

54. Magurran A. Ecological diversity and its measurement. Princeton, NJ, USA: Princeton University Press. 1988; https://doi.org/10.1007/978-94-015-7358-0

55. Malik DP, Singh IJ. Crop diversification-An economic analysis. Indian J Agric Res. 2002; 36(1):61-64

56. Mandal R, Bezbaruah M. Diversification of cropping pattern: Its determinants and role in flood affected agriculture of Assam Plains. Indian Journal of Agricultural Economics. 2013; 68 (2): 170-181.

57. Martey E, Al-Hassan RM, Kuwornu JK. Commercialization of smallholder agriculture in Ghana: A Tobit regression analysis. Afr. J. Agric. Res. 2012; 7, 2131-2141.

58. Matshe I, Young T. Off-farm labour allocation decisions in small-scale rural households in Zimbabwe. Agric. Econ. 2004; 30, 175-186.

59. Mazunda J, Kankwamba H, Pauw K. Food and nutrition security implications of crop diversification in Malawi's farm households. In Agriculture, food security, and nutrition in Malawi: Leveraging the links, eds. Noora-Lisa Aberman, Janice Meerman, and Todd Benson. Chapter 5, Pp. 53-60 Washington, D.C.2018; International Food Policy Research Institute (IFPRI). https://doi.org/10.2499/9780896292864_05

60. Mesfin W, Fufa B, \& Haji J. Pattern, trend and determinants of crop diversification: Empirical evidence from smallholders in Eastern Ethiopia. Journal of Economics and Sustainable Development. 2011; 2(8), 78-89.

61. Michler JD, Josephson AL. To specialize or diversify: Agricultural diversity and poverty dynamics in Ethiopia. World Development, 2017; 89, 214-226.

62. MoFED. Growth and Transformation Plan (GTP) 2015/16-2019/20. 2015; Addis Ababa, Ethiopia. 63. Moffatt PG. Hurdle models of loan default. J. Oper. Res. Soc. 2005; 56, 1063-1071. 
64. Mugendi NE. Crop diversification: A potential strategy to mitigate food insecurity by smallholders in sub-Saharan Africa. Journal of Agriculture, Food Systems, and Community Development. 2013; 3(4), 63-69.

65. Mukherjee A. Evaluation of the policy of crop diversification as a strategy for reduction of rural poverty in India. In: Poverty reduction policies and practices in developing Asia. Economic studies in inequality, social exclusion and well-being Eds: Heshmati, A., Maasoumi, E, Wan, G. Asian Development Bank 2015 https://doi.org/10.1007/978-981-287-420-7_7

66. Mussema R, Belay K, Dawit A, Shahidur R. Determinants of Crop Diversification in Ethiopia: Evidence from Oromia Region. Ethiop. J. Agric. Sci. 2015; 25(2) 65-76

67. Ojo M, Ojo A, Odine A, Ogaji A. Determinants of crop diversification among small - scale food crop farmers in north central, Nigeria. Production Agriculture and Technology Journal, 2014; 10(2), 1-11.

68. Pellegrini L, Tasciotti L. Crop diversification, dietary diversity and agricultural income: empirical evidence from eight developing countries. Canadian Journal of Development Studies. 2014; 35(2), 211 227.

69. Piya L, Lall K. Determinants of adaptation practices to climate change by Chepang households in the rural Mid-Hills of Nepal. Regional Environmental Change. 2013; 437-447.

70. Poudel S, Basavaraja H, Kunnal L, Mahajanashetti S, Bhat A. Crop diversification in Karnataka: An economic analysis. 2012; Department of Agricultural Economics, University of Agricultural Sciences, Dharwad, Karnataka.

71. Rahm R, Huffman E. The Adoption of Reduced Tillage: The Role of Human Capital and Other Variables. American Journal of Agricultural Economics.1984; 66, (4), 405-413. https://doi.org/10.2307/1240918

72. Rehima M, Belay M, Dawit A, Shahidur R,. Factors affecting farmers' crops diversification: Evidence from SNNPR, Ethiopia. Int. J. of Agric. Sci. 2013; 3(6), 558-565.

73. Rehima M, Belay, K, Dawit A, Rashid S. Determinants of Crop Diversification in Ethiopia: Evidence from Oromia Region. Ethiop. J. Agric. Sci. 2015; 25(2), 65-76

74. Ruben R, Van den Berg M. Nonfarm employment and poverty alleviation of rural farm households in Honduras. World Development. 2001; 29(3), 549-560.

75. Sandretto CL, Mishra AK, El-Osta HS. Factors affecting farm enterprise diversification. Agricultural finance review. 2004; 64(2), pp.151

76. Sibhatu KT, Krishna V, Qaim M. Production diversity and dietary diversity in smallholder farm households. 2015; Proceedings of the National Academy of Sciences USA (PNAS) 112: 10657-10662. https://doi.org/10.1073/pnas.1510982112

77. Sichoongwe K, Laqrene M, Ng'ng'ola D, Temb G. The Determinants and Extent of Crop Diversification among Smallholder Farmers. A case study of Southern Province, Zambia, Malawi Strategy Support Program, Working Papers 05, Washington DC. 2014;

78. https://doi.org/10.5539/jas.v6n11p150

79. Singh I, Squire L, Strauss J. Agricultural household models: extensions, policy and applications. 1986; John Hopkins University, Baltimore 
80. Sisay D. Agricultural Technology Adoption, Crop Diversification and Efficiency of Maize-Dominated Smallholder Farming System in Jimma Zone, Southwestern Ethiopia. (Electronic Thesis or Dissertation). 2016; Haramaya University, Ethiopia

81. Swades P, Shyamal K. Implications of the methods of agricultural diversification in reference with Malda district: drawback and rationale. International Journal of Food, Agriculture and Veterinary Sciences. 2012; 2 (2), 97-105.

82. Taylor J, Adelman I. Agricultural Household Models: Genesis, Evolution, and Extensions. Review of Economics of the Household. 2003; 1(1), 33-58.

83. Truscott L, Aranda D, Nagarajan P, Tovignan S, Travaglini AL. A snapshot of crop diversification in organic cotton farms. In Discussion paper. 2009; Soil Association

84. Tura EG, Goshu D, Demisie T, Kenea T. Determinants of market participation and intensity of marketed surplus of teff producers in Bacho and Dawo Districts of Oromia State, Ethiopia. J. Agric. Econ. Dev. $2016 ; 5,20-32$.

85. UNDP (United Nation Development Program). Towards building resilience and supporting transformation in Ethiopia. Annual Report, 2016. Addis Ababa, Ethiopia

86. Van den Broeck G, Maertens, M. Horticultural exports and food security in developing countries. Global Food Security. 2016; 10, 11-20.

87. Van Dusen ME, Taylor JE. Missing markets and crop diversity: evidence from Mexico. Environment and Development Economics. 2005; 10 (4), 513-531.

88. Veljanoska S. Agricultural risk and remittances: the case of Uganda. International Congress, EAAE. 2014; Congress 'Agri-Food and Rural Innovations for Healthier Societies', August 26-29, 2014; Ljubljana, Slovenia. European Association of Agricultural Economists.

89. Wanyoike F, Mtimet N, Ndiwa N, Marshall K, Godiah L, Warsame A. Knowledge of livestock grading and market participation among small ruminant producers in northern Somalia. East Afr. Agric. For. J. 2015; $81,64-70$.

90. Winters P, Cavatassi R, Lipper L. Sowing the seeds of social relations: The role of social capital in crop diversity. ESA Working Paper. 2006; No. 6, (16): pp. 1- 40.

91. World Bank. Productive Diversification of African Agriculture and its Effects on Resilience and Nutrition. 2018; USA.

92. Yamane T. Statistics: An Introductory Analysis, 2nd Edition. New York: 1967; Harper and Row.

93. Yami M, Teklu T, Adam B. Determinants of farmers' participation decision on local seed multiplication in Amhara region, Ethiopia: A double hurdle approach. Int. J. Sci. Res. 2013; 2, 423-430.

\section{Figures}




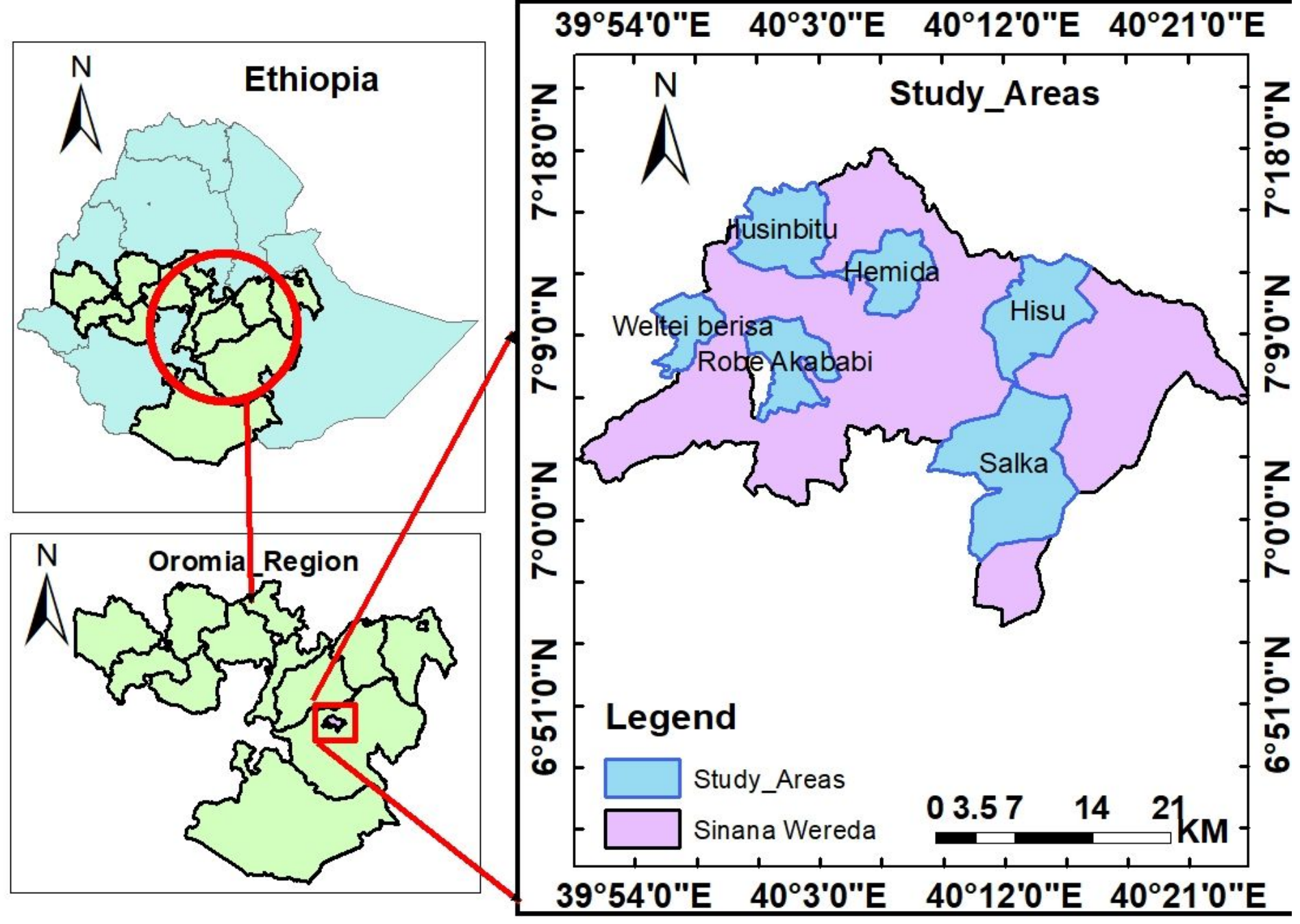

Figure 1

Map of Study area 


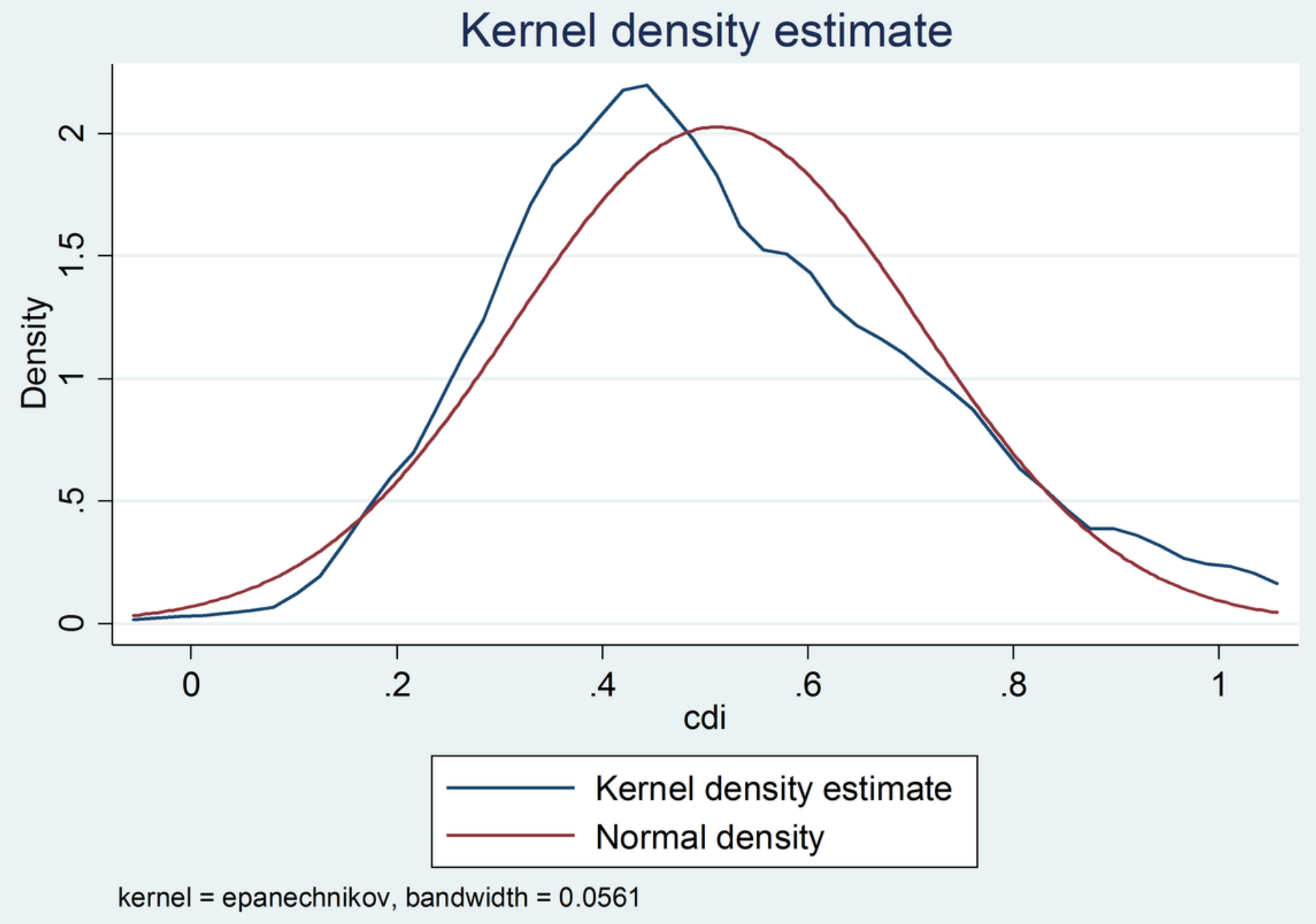

Figure 2

Kernel density estimate for crop diversification index 